\title{
Production of Vegetables and Artichokes Is Associated with Lower Cardiovascular Mortality: An Ecological Study
}

\author{
Alberto Arnedo-Pena ${ }^{1,2,3, *(\mathbb{D})}$, Joan Puig-Barberà 4 (D), Juan Bellido-Blasco ${ }^{2,3,5}$, \\ M- Angeles Romeu-Garcia ${ }^{2}$, M- Rosario Pac-Sa ${ }^{2}$ and Francisco Guillen-Grima ${ }^{1}$ (D) \\ 1 Health Sciences Department, Public University Navarra, 31008 Pamplona, Spain; f.guillen.grima@gmail.com \\ 2 Epidemiology Division Public Health Center, 12003 Castello de la Plana, Spain; bellido_jua@gva.es (J.B.-B.); \\ romeu_man@gva.es (M.A.R.-G.); charopac@gmail.com (M.R.P.-S.) \\ 3 Epidemiology and Public Health (CIBERESP), 28029 Madrid, Spain \\ 4 Vaccines Research Area FISABIO, 46020 Valencia, Spain; jpuigb55@gmail.com \\ 5 Epidemiology Department, Jaume I University, 12006 Castelló de la Plana, Spain \\ * Correspondence: albertoarnedopena@gmail.com
}

Received: 29 July 2020; Accepted: 5 September 2020; Published: 10 September 2020

\begin{abstract}
Mortality due to cardiovascular disease (CVD), including cerebrovascular disease (CED) and ischaemic heart disease (IHD), was considerably different in eight municipalities of the province of Castellón, Community of Valencia (Spain) during the period of 1991-2011. In addition, these villages showed differences in agricultural practices and production. Since high vegetable consumption has been linked to decreased all-cause, CVD, and CED mortalities, we hypothesized that the diversity in vegetable and artichoke production, used as proxies for their consumption, could be associated with the diversity of mortality rates. In order to test our hypothesis, we estimated the smoothed standardized mortality ratios (SMRs) of CVD, CED, and IHD mortalities and a directed, age-adjusted mortality rate (AMR). We used a multilevel linear regression analysis to account for the ecological nature of our study. After adjustment, the CVD and CED SMRs were inversely associated with vegetable and artichoke production, with a reduction in SMRs for CVD: -0.19 (95\% Confidence Interval $[C I]-0.31$ to -0.07$)$ and $-0.42(95 \% \mathrm{CI}-0.70$ to -0.15$)$ per hectare $/ 10^{3}$ inhabitants, respectively. The SMRs for CED also decreased: -0.68 (95\% CI -1.61 to -0.19$)$ and -1.47 (95\% CI -2.57 to -0.36 ) per hectare $/ 10^{3}$ inhabitants, respectively. The SMRs for IHD were not associated with vegetal and artichoke production. When the directed AMR was used, CED mortality was consistent with the previous results, whereas the CVD mortality association was lost. Our results indicate that vegetable and artichoke production may act as protective factors of CED and CVD mortalities.
\end{abstract}

Keywords: mortality; cardiovascular; cerebrovascular; vegetables; artichokes; agriculture; municipalities; multilevel; ecology

\section{Introduction}

Mortality from cardiovascular diseases (CVD), including cerebrovascular disease (CED), is the primary cause of death in the population, and many risk factors have been identified through epidemiological and medical studies [1-5]. CVD and CED mortalities present large geographic differences, suggesting that factors at a local level may play a role in the observed variability. To explain these differences, research on mortality in small areas is useful to generate hypotheses on potential causes or risk factors, health resource distribution, and preventive measures [6-8]. In general, the first stage is the detection of local differences in CVD mortality. If differences are found, a second stage is carried out to estimate risks and protective factors [9-12]. 
Using the Analysis Geographic Epidemiologic (AGEPI) mortality program [13-15], we observed differences in CVD and CED mortalities in the eight municipalities with 25,000 or more inhabitants in the Castellón province in the Community of Valencia (CV); today a new version is available [16]. There is a difference between these municipalities in their agricultural practice: citrus cultivation is predominant in all of the municipalities except one, Benicarló, where vegetables, mainly artichokes (Cynara scolymus), have high production levels. Consumption of vegetables and fruits is associated with lower all-cause, CVD, CED, and ischaemic heart disease (IHD) mortality [17-19]. Artichokes have properties, such as lipid and glycemic reduction and high levels of $\mathrm{K}$ with a low $\mathrm{Na} / \mathrm{K}$ index, that may prevent hypertension and CVD [20,21].

Our hypothesis was that the production of vegetables and artichokes as a proxy of their consumption is associated with lower CVD and CED mortalities. To test this, we conducted an ecological study considering all-cause, CVD, CED, and IHD mortalities in eight municipalities in the Castellón province.

\section{Materials and Methods}

We conducted an ecological study considering all-cause, CVD, CED, and IHD mortalities during the period from 1991 to 2011 in the eight municipalities in the province of Castellón with a population of 25,000 or more inhabitants in 2011. This province is divided into three health departments: Vinaròs in the north, Castelló de la Plana in the center, and Vila-real in the south, with 90,816, 283,021 and 187,258 inhabitants, respectively.

The municipalities were Almassora (25,945 inhabitants), Benicarló (26,553 inhabitants), Borriana (27,385 inhabitants), Castelló de la Plana (176,300 inhabitants), Onda (25,704 inhabitants), la Vall d'Uixó (32,864 inhabitants), Vila-real (51,168 inhabitants), and Vinaròs (28,508 inhabitants). The health care system was the same in the 8 studied municipalities, and the CVD medical attention was comparable in the three health departments (Vinaròs, Castelló de la Plana, and Vila-real) with a ratio of 1299, 1497, and 1538 physicians per 1000 inhabitants, respectively, and a ratio of 1613, 1756, and 2064 nurses per 1000 inhabitants, respectively [22].

The province of Castellón is located on Spain's east, Mediterranean coast, with 576,889 inhabitants and an area of $6612 \mathrm{~km}^{2}$. The population is concentrated in the north (El Baix-Maestrat), in Benicarló and Vinaròs, in the central part (La Plana Alta), in the cities of Castelló de la Plana, the administrative capital, and Almassora, as well as in the southern part (Plana Baixa), in Borriana, Vila-real, la Vall d'Uixó, and Onda. Almassora and Vila-real are located adjacent to Castelló de la Plana, $5.2 \mathrm{~km}$ and $7.6 \mathrm{~km}$ apart, respectively, and Borriana is located $11.1 \mathrm{~km}$ south of Castelló; all of these municipalities are on or near the Mediterranean coast. In the interior, la Vall d'Uixó and Onda are located $24.5 \mathrm{~km}$ and $19.3 \mathrm{~km}$ from Castelló de la Plana, respectively. Vinaròs and Benicarló are near each other $(7.2 \mathrm{~km}$ apart) and are located $70 \mathrm{~km}$ and $62.3 \mathrm{~km}$ away from Castelló de la Plana, respectively (Figure 1). Agricultural production is based on citrus fruits in all of these municipalities, with the exception of Benicarló, where vegetable production predominates with artichokes as the more prevalent vegetable. Industrial production involving ceramics is located in Vila-real and Onda, and the petro-chemistry industry is based in Castelló.

The number of CVD, CED, and IHD deaths was obtained from the AGEPI mortality program of the Conselleria de Sanitat Universal and Salud Pública of the Generalitat Valenciana [13]. The causes of mortality were coded according to the 9th and 10th International Classification of Diseases (ICD): CVD (codes 100-199; 390-459); CED (codes 160-169; 430-438); IHD (codes 120-125; 410-419) [23].

We obtained socio-economic and demographic data from the Generalitat Valenciana (Argos, Banc de dates Territorial) and from the National Statistics Institute (2001-2011 censuses) [24-26]. We collected information on the number of inhabitants, sex distribution, population aged 65 years and above, foreign-born population, household income in euros, unemployment, illiterate population, percentages of occupations in agriculture, industry, services, and construction as variables for 
adjustment, and agricultural production of vegetables, artichokes, and citrus fruits per hectare per 1000 inhabitants (median for the period 2002-2011) as explicative variables.

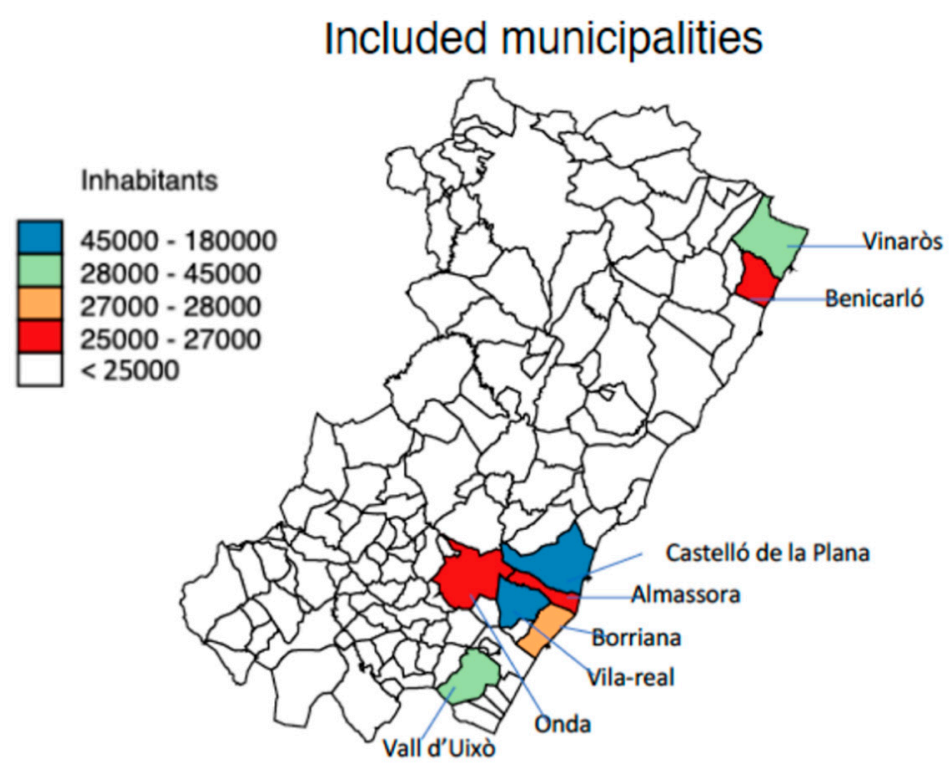

Figure 1. Geographical locations and populations of the included municipalities.

\section{Statistical Methods}

We estimated the smoothed standardized mortality ratios (SMRs) using Clayton and Kaldor's methodology [27] and compared the observed mortality with the expected mortality in the CV, and calculated the age-adjusted mortality rate (AMR) by direct standardization of the CV age distribution per 100,000 inhabitants during the study period [13]. The SMRs were calculated from each of the 8 municipalities' observed mortality and the expected mortality from Valencia's population. Given that calculating the SMR is a preferred method to study mortality in small areas [28], we used AMR calculation as a sensitivity analysis for the SMR results, considering direction and significance. Using the Directed Acyclic Graphic (DAG) [29] (Figure 2), we studied the relationship of exposure to agricultural production with all-cause, CVD, CED, and IHD mortality outcomes, and potential confounding factors: sex, population aged 65 years and above, foreign-born, household income, illiteracy, and municipality. Other potential confounders such as unemployment, particulate matter (PM10) and nitrogen dioxide (NO2) levels, coastal proximity, and drinking water hardness were studied.

We used a multilevel linear regression analysis with municipality as the level variable to estimate associations between mortality outcomes and exposure variables in models adjusted for potential confounders assuming normal data distribution. A residual interclass correlation (ICC) indicated the total explained variance by the models. We used Log likelihood, Akaike's information criterion and Bayesian information criterion to check the goodness of fit of the models. We estimated the Moran's I index [30] to evaluate the spatial autocorrelations of the SMRs and AMR among the municipalities and used Spearman's nonparametric correlation to detect relationships among exposure variables. We performed all of the analyses with Stata ${ }^{\circledR}$ version 14 (StataCorp, College Station, TX, USA. No Investigation Review Board approbation was required because all data were anonymous-aggregated data of public domain. 


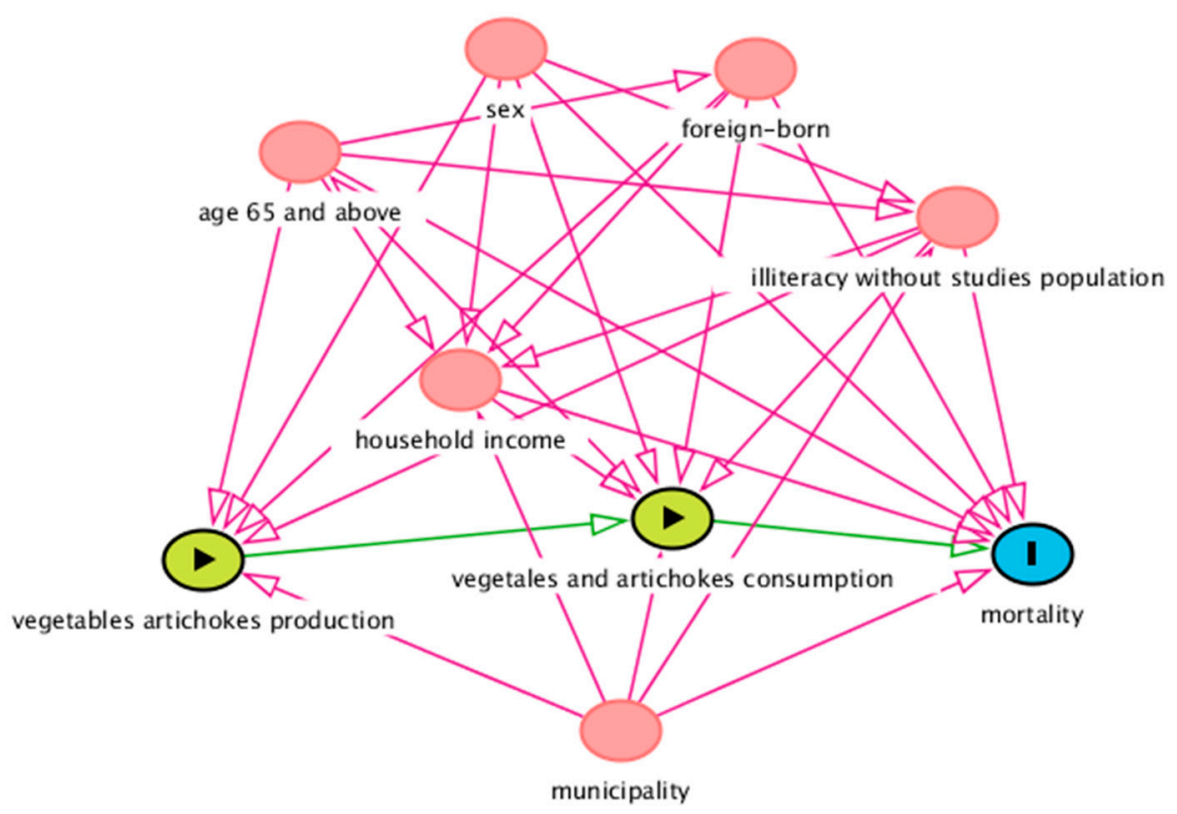

Figure 2. Directed Acyclic Graph (DAG) of the effect of vegetable and artichoke production and consumption (exposure) on mortality (outcome). Ancestors of exposure and outcome (red color). Based on DAGitty version 3.0. ( Johannes Textor, Nijmegen, The Netherlands).

\section{Results}

The socio-economic characteristics of the eight municipalities (Table 1) indicated some important differences. Castelló de la Plana, the province capital, was the biggest municipality, and Almassora the smallest. The foreign-born population was higher in Benicarló and lower in la Vall d'Uixó. Household income differences were small, but unemployment was higher in Onda and lower in Benicarló and Vinaròs. Industrial occupations were more common in Onda and Vila-real. Agricultural hectares per inhabitant were higher in Onda and Vinaròs and lower in Castelló. A great contrast between Benicarló and the other cities was observed when vegetable and artichoke production levels were compared. Benicarló had the highest level of vegetable and artichoke production, whereas in Onda and Vila-real, vegetable and artichoke production were almost null. Despite high citrus production in the province, differences were considerable; Borriana and Vinaròs had the highest production level and Castelló the lowest. Out of the eight municipalities, except Onda and Vall d'Uixó, six were located in coastal proximity, and all of the municipalities had a Mediterranean climate, although rains were more present in Benicarló and Vinaròs. Water hardness was elevated in these municipalities, with higher levels in Castelló and the lowest in Vinaròs. Air pollution, measured by PM10 and NO2 levels, was higher in Almassora and lower in Benicarló and Vinaròs.

Spearman correlation coefficients among explicative variables are shown in Table 2. Vegetable and artichoke production levels had strong positive correlations (0.91); artichoke production correlated negatively with unemployment (-0.92) and positively with coastal distance (0.87). A strong negative correlation between foreign-born population percentage and unemployment was found (-0.83). Pm10 and NO2 negatively correlated with the percentage of population aged 65 years and above and agricultural and vegetable production. 
Table 1. Socio-economic characteristics of the eight municipalities, agricultural production in hectares per 1000 inhabitants, and environmental indicators (Castellón, 1991-2011 period).

\begin{tabular}{|c|c|c|c|c|c|c|c|c|}
\hline Variables & Almassora & Benicarló & Borriana & Castelló & Onda & $\begin{array}{c}\text { Vall } \\
\text { d'Uixó }\end{array}$ & $\begin{array}{l}\text { Vila- } \\
\text { Real }\end{array}$ & Vinaròs \\
\hline \multicolumn{9}{|c|}{ Socio-economic indicators } \\
\hline Health departments & 2 & 1 & 3 & 2 & 3 & 3 & 3 & 1 \\
\hline Population 1 & 17,384 & 21,015 & 27,385 & 150,444 & 20,021 & 29,638 & 42,961 & 22,960 \\
\hline $\begin{array}{c}\text { Population aged } 65 \text { years } \\
\text { and above } \%\end{array}$ & 14.2 & 17.8 & 17.1 & 17.8 & 15.7 & 19.1 & 15.8 & 18.1 \\
\hline Foreign-born \% & 14.8 & 21.2 & 15.9 & 15.9 & 12.5 & 7.1 & 11.8 & 17.8 \\
\hline $\begin{array}{c}\text { Household income in } \\
\text { euros }\end{array}$ & 14,064 & 13,824 & 14,077 & 15,519 & 13,815 & 13,754 & 14,436 & 14,198 \\
\hline Unemployment \% & 18.1 & 15.3 & 16.8 & 17.9 & 21.2 & 18.67 & 19.6 & 15.3 \\
\hline Illiteracy \% & 32.1 & 22.6 & 22.4 & 20.4 & 23.3 & 24.0 & 24.4 & 22.9 \\
\hline \multicolumn{9}{|c|}{ Occupation $\%$} \\
\hline Agriculture \% & 3.2 & 8.8 & 10.0 & 2.7 & 5.9 & 8.6 & 4.8 & 8.7 \\
\hline Industrial \% & 22.1 & 18.7 & 22.7 & 17.2 & 33.1 & 20.5 & 26.6 & 16.7 \\
\hline Construction $\%$ & 11.8 & 10.1 & 7.8 & 6.6 & 8.7 & 9.3 & 8.6 & 8.2 \\
\hline Services $\%$ & 62.9 & 62.4 & 59.5 & 73.5 & 52.3 & 61.7 & 60.0 & 66.4 \\
\hline \multicolumn{9}{|c|}{ Agriculture production $\mathrm{Ha}^{2}$} \\
\hline Agriculture 2 & 104.3 & 181.0 & 130.7 & 46.0 & 404.0 & 189.1 & 88.8 & 335.9 \\
\hline Herbaceous ${ }^{2}$ & 8.7 & 58.9 & 4.7 & 7.5 & 14.6 & 4.3 & 4.7 & 37.0 \\
\hline Woody plants ${ }^{2}$ & 90.0 & 105.8 & 122.9 & 29.2 & 242.2 & 77.9 & 80.2 & 281.5 \\
\hline Pastures $^{2}$ & 5.8 & 15.8 & 3.1 & 8.1 & 69.9 & 106.0 & 3.9 & 16.3 \\
\hline Forest species $^{2}$ & 0.15 & 1.2 & 0.01 & 1.21 & 89.4 & 0.02 & 0.0 & 1.04 \\
\hline Vegetables ${ }^{3}$ & 1.1 & 64.0 & 0.9 & 0.2 & 0.2 & 0.3 & 0.0 & 10.3 \\
\hline Artichoke ${ }^{3}$ & 0.5 & 27.4 & 0.2 & 0.1 & 0.0 & 0.03 & 0.0 & 2.8 \\
\hline Citrus $^{3}$ & 94.4 & 52.3 & 111.7 & 21.7 & 182.7 & 70.9 & 76.2 & 204.6 \\
\hline \multicolumn{9}{|c|}{ Environmental indicators } \\
\hline $\begin{array}{l}\text { Water hardness in } \\
\text { French degrees } 4\end{array}$ & $35.8^{\circ}$ & $35.5^{\circ}$ & $45.8^{\circ}$ & $49.5^{\circ}$ & $48.9^{\circ}$ & $28.9^{\circ}$ & $45.0^{\circ}$ & $30.4^{\circ}$ \\
\hline Coastal distance in $\mathrm{km}$ & 5.0 & 0.10 & 5.7 & 5.0 & 10.6 & 20.0 & 8.4 & 0.10 \\
\hline PM10 mg/m 35 & 36.58 & 16.03 & 27.38 & 29.08 & 21.93 & $19.0^{6}$ & 31.64 & 16.03 \\
\hline $\mathrm{NO} 2 \mathrm{mg} / \mathrm{m}^{35}$ & 22.7 & 6.25 & 16.22 & 21.49 & 9.0 & $6.5^{6}$ & 19.20 & 6.25 \\
\hline
\end{tabular}

${ }^{1}$ Median population (1991-2011). ${ }^{2}$ Land in hectares per 1000 inhabitants: Census 2011. ${ }^{3}$ Median hectare production (2002-2011) per 1000 inhabitants. Portal estadístico Generalitat Valenciana [25]. ${ }^{4}$ Annual mean values. Sources: Facsa and Sorea water distribution companies www.facsa.com www.sorea.cat. ${ }^{5}$ Annual mean concentration (2001-2011). Source: Calidad Ambiental. Generalitat Valenciana [24]. Annual mean concentration (2003-2011).

${ }^{6}$ Vall d'Uixó (2010-2011).

The SMRs for all-cause and CVD mortalities are presented in Table 3. For males, the SMR for all-cause mortality was higher than 100 in all cities except Benicarló. For CVD, CED, IHD, and CVD plus IHD mortalities, Benicarló had the lowest SMRs and Borriana the highest. Benicarló had SMRs lower than 100 for all of these diseases. For females, as with males, Benicarló had the lowest SMRs for all-cause and CVD mortalities. We observed higher differences across the municipalities in the case of females: Onda had the highest SMR for all-cause mortality, Vila-real had the highest for CVD, Borriana for CED, and Castelló for IHD.

The AMRs for all-cause and cardiovascular disease mortalities are presented in Table 4. The results are parallel with the SMRs. For males, Benicarló had the lowest AMRs for all-cause and CVD mortalities, and Borriana the highest. The AMR differences across the municipalities are elevated, being the highest for CED and the lowest for IHD. For females, Benicarló had the lowest AMRs for all-cause and CVD mortalities; Onda had the highest AMRs for all-cause and CVD mortalities, followed by Borriana in CVD mortality and Castelló in IHD mortality. 
Table 2. Spearman correlation coefficients among independent variables (Castellón, 1991-2011 period).

\begin{tabular}{|c|c|c|c|c|c|c|c|c|c|c|c|c|c|}
\hline Variables & (a) & (b) & (c) & (d) & (e) & (f) & (g) & (h) & (i) & (j) & (k) & (1) & (m) \\
\hline Population aged 65 years and above \% (a) & 1.0 & & & & & & & & & & & & \\
\hline Household income in euros (b) & -0.06 & 1.0 & & & & & & & & & & & \\
\hline Foreign-born \% (c) & 0.16 & 0.38 & 1.0 & & & & & & & & & & \\
\hline Illiteracy \% (d) & -0.41 & -0.33 & -0.71 & 1.0 & & & & & & & & & \\
\hline $\begin{array}{c}\text { Agriculture } \\
\text { Production }^{1}(e)\end{array}$ & 0.22 & -0.69 & -0.17 & 0.10 & 1.0 & & & & & & & & \\
\hline Vegetables $^{1}(\mathrm{f})$ & 0.22 & 0.33 & 0.52 & 0.10 & 0.40 & 1.0 & & & & & & & \\
\hline Artichoke $^{1}(g)$ & 0.25 & 0.04 & 0.75 & -0.29 & 0.05 & 0.91 & 1.0 & & & & & & \\
\hline Citrus $^{1}(\mathrm{~h})$ & -0.25 & -0.12 & -0.22 & 0.24 & 0.62 & 0.21 & -0.01 & 1.0 & & & & & \\
\hline Unemployment \% (i) & -0.44 & -0.57 & -0.83 & -0.57 & 0.05 & -0.43 & -0.92 & 0.01 & 1.0 & & & & \\
\hline Coastal distance in $\mathrm{km} \mathrm{(j)}$ & -0.11 & -0.42 & -0.88 & 0.36 & 0.14 & -0.66 & 0.87 & 0.02 & 0.84 & 1.0 & & & \\
\hline PM10 mg $/ \mathrm{m}^{3} /(\mathbf{k})$ & -0.70 & 0.40 & -0.31 & 0.37 & -0.72 & -0.56 & -0.41 & -0.14 & 0.49 & 0.25 & 1.0 & & \\
\hline $\mathrm{NO} 2 \mathrm{mg} / \mathrm{m}^{3}(\mathrm{l})$ & -0.64 & 0.42 & -0.19 & 0.23 & -0.74 & -0.54 & -0.35 & -0.22 & 0.42 & 0.19 & 0.98 & 1.0 & \\
\hline Water hardness ${ }^{2}(\mathrm{~m})$ & -0.54 & 0.45 & 0.19 & -0.40 & 0.40 & -0.57 & -0.41 & -0.10 & 0.29 & 0.11 & 0.51 & 0.59 & 1.0 \\
\hline
\end{tabular}

${ }^{1}$ Land in hectares per 1000 inhabitants. ${ }^{2}$ French degrees. Italic: $p$-value $<0.05$; Bold: $p$-value $<0.01$.

Table 3. Smoothed standardized mortality ratios (SMRs): males and females (Castellón, 1991-2011 period).

\begin{tabular}{|c|c|c|c|c|c|c|c|c|c|c|}
\hline \multirow[t]{2}{*}{ Municipality } & \multicolumn{2}{|c|}{$\begin{array}{l}\text { All-Cause } \\
\text { Mortality }\end{array}$} & \multicolumn{2}{|c|}{$\begin{array}{l}\text { Cardiovascular } \\
\text { Disease (CVD) }\end{array}$} & \multicolumn{2}{|c|}{$\begin{array}{l}\text { Cerebrovascular } \\
\text { Disease (CED) }\end{array}$} & \multicolumn{2}{|c|}{$\begin{array}{l}\text { Ischaemic Heart } \\
\text { Disease (IHD) }\end{array}$} & \multicolumn{2}{|c|}{ CED + IHD } \\
\hline & Males & Females & Males & Females & Males & Females & Males & Females & Males & Females \\
\hline Almassora & 101.2 & 103.8 & 99.2 & 115.5 & 98.2 & 98.5 & 110.2 & 101.1 & 103.8 & 99.1 \\
\hline Benicarló & 104.7 & 111.8 & 94.9 & 97.7 & 75.5 & 71.4 & 94.1 & 82.1 & 83.3 & 73.9 \\
\hline Borriana & 95.4 & 101.0 & 120.6 & 116.3 & 137.0 & 141.6 & 113.4 & 97.6 & 126.5 & 129.3 \\
\hline Castelló & 98.1 & 107.1 & 106.4 & 106.5 & 100.6 & 98.9 & 108.1 & 117.9 & 104.1 & 104.3 \\
\hline Onda & 115.2 & 109.1 & 111.3 & 120.2 & 119.3 & 133.1 & 107.2 & 87.0 & 104.1 & 120.1 \\
\hline Vall d'Uixó & 108.2 & 111.7 & 105.0 & 116.1 & 103.8 & 106.4 & 107.2 & 88.2 & 114.0 & 101.0 \\
\hline Vila-real & 104.1 & 106.2 & 113.7 & 121.0 & 128.3 & 138.4 & 101.3 & 96.2 & 115.9 & 126.4 \\
\hline Vinaròs & 100.7 & 103.0 & 100.6 & 102.0 & 85.4 & 101.7 & 109.0 & 90.9 & 96.3 & 98.5 \\
\hline
\end{tabular}


Table 4. Age-adjusted mortality rates per 100,000 inhabitants: males and females (Castellón, 1991-2011 period).

\begin{tabular}{ccccccccccc}
\hline \multirow{2}{*}{ Municipality } & \multicolumn{2}{c}{$\begin{array}{c}\text { All-Cause } \\
\text { Mortality }\end{array}$} & \multicolumn{2}{c}{$\begin{array}{c}\text { Cardiovascular } \\
\text { Disease (CVD) }\end{array}$} & \multicolumn{2}{c}{$\begin{array}{c}\text { Cerebrovascular } \\
\text { Disease (CED) }\end{array}$} & \multicolumn{2}{c}{$\begin{array}{c}\text { Ischaemic Heart } \\
\text { Disease (IHD) }\end{array}$} & CED + IHD \\
& Males & Females & Males & Females & Males & Females & Males & Females & Males & Females \\
Almassora & 952.2 & 866.2 & 287.7 & 382.5 & 80.8 & 109.8 & 80.2 & 46.4 & 161.1 & 156.1 \\
Benicarló & 891.9 & 812.0 & 274.8 & 335.5 & 60.7 & 78.5 & 68.0 & 36.2 & 128.7 & 114.7 \\
Borriana & 1082.9 & 894.8 & 350.8 & 399.0 & 114.7 & 159.2 & 82.5 & 44.8 & 197.2 & 203.4 \\
Castelló & 976.5 & 834.2 & 378.3 & 365.8 & 83.5 & 110.9 & 78.5 & 53.2 & 162.0 & 164.1 \\
$\quad$ Onda & 977.7 & 929.0 & 323.0 & 414.4 & 99.2 & 151.5 & 77.6 & 38.5 & 176.7 & 190.0 \\
$\quad$ Vall & 948.0 & 885.3 & 303.7 & 399.0 & 85.6 & 118.6 & 71.2 & 39.3 & 159.9 & 157.7 \\
d'Uixó & & & & & & & & & & \\
Vila-real & 1027.0 & 925.3 & 331.2 & 414.1 & 106.9 & 155.7 & 73.2 & 43.8 & 180.1 & 198.8 \\
Vinaròs & 996.4 & 853.6 & 292.4 & 350.2 & 69.5 & 113.7 & 79.5 & 41.0 & 148.9 & 154.6 \\
\hline
\end{tabular}


The spatial autocorrelation on SMRs and AMRs was significant for CED plus IHD. CVD was only found to be significant on SMRs (Table 5).

Table 5. Spatial autocorrelation following Moran's I index of the smoothed standardized mortality ratios (SMRs) and age-adjusted mortality rates (AMRs) of the eight municipalities (Castellón, 1991-2011 period).

\begin{tabular}{cccc}
\hline SMRs & Moran's I Index & Z & $p$-Value \\
\hline All-cause mortality & -0.013 & 0.620 & 0.268 \\
Cardiovascular (CVD) mortality & 0.110 & 2.015 & 0.022 \\
Cerebrovascular (CED) mortality & 0.073 & 1.596 & 0.055 \\
Ischaemic heart disease (IHD) mortality & -0.008 & 0.741 & 0.229 \\
CED + IHD mortality & 0.110 & 2.052 & 0.020 \\
AMRs & & & \\
All-cause mortality & 0.006 & 0.699 & 0.242 \\
Cardiovascular (CVD) mortality & 0.046 & 1.292 & 0.098 \\
Cerebrovascular (CED) mortality & 0.073 & 1.199 & 0.115 \\
Ischaemic heart disease (IHD) mortality & 0.006 & 0.817 & 0.207 \\
CED + IHD mortality & 0.113 & 2.083 & 0.019 \\
\hline
\end{tabular}

With the SMRs and AMRs as dependent variables, and agricultural, vegetable, artichoke, and citrus production as independent variables adjusted for other covariates (Table 6), artichoke production was associated with lower SMRs or AMRs in all instances.

All-cause mortality was inversely associated with vegetable and artichoke production, but ICCs were not computable; we found no association between agricultural and citrus production with all-cause mortality. CVD mortality (SMR) was reduced: -0.19 (95\% CI -0.31 to -0.07$)$ for vegetables and -0.42 ( $95 \%$ CI -0.79 to -0.04$)$ for artichokes per hectare $/ 10^{3}$ inhabitants, with low ICCs of 0.07 and 0.10 , respectively. For CEV, the SMRs were lower: -0.68 (95\% CI -1.16 to -0.19$)$ for vegetables and $-1.4(95 \%$ CI -2.57 to -0.36$)$ for artichokes per hectare $/ 10^{3}$ inhabitants, with high ICCs of 0.72 and 0.73 , respectively. Agricultural and citrus production levels were not associated with CVD or CED mortalities (SMRs). IHD mortality (SMRs) was not associated with any of the independent variables and ICCs were not computable. For CED plus IHD mortality, when vegetable and artichoke production increased, the SMRs decreased, with ICCs of 0.59 and 0.61 , respectively.

The AMR multilevel linear regression sensitivity analysis results are reported in Table 6 . The AMR results closely resemble those obtained for the SMRs. All causes of mortality were inversely associated with vegetable and artichoke production, but the ICCs were not computable, and agricultural and citrus production levels were not associated with all-cause mortality. CVD mortality was not associated with any of the independent variables. CED mortality was inversely associated with vegetable and artichoke production with ICCs of 0.39 and 0.41 , respectively; agricultural and citrus production levels were not associated with any change in CED mortality. IHD mortality was inversely associated with vegetable and artichoke production but ICCs were not computable; agricultural and citrus production levels were not associated with IHD mortality. CED plus IHD mortality was inversely associated with vegetable and artichoke production with ICCs of 0.56 and 0.58, respectively. Agricultural and citrus production levels were not associated with CED plus IHD mortality. 
Table 6. Multilevel linear regression: smoothed standardized mortality ratio (SMR) and age-adjusted mortality rate (AMR) of mortality among eight municipalities of the Castellón province. Adjusted models for sex, population aged 65 years and above, foreign-born, household income, illiteracy level, and municipality (Castellón, 1991-2011 period).

\begin{tabular}{|c|c|c|c|c|c|c|}
\hline \multirow[t]{2}{*}{ Factors } & \multicolumn{3}{|c|}{ SMRs } & \multicolumn{3}{|c|}{ AMR } \\
\hline & $\mathrm{RC}^{1}\left(95 \% \mathrm{CI}^{2}\right)$ & $p$-Value & $\mathrm{ICC}^{3}(95 \% \mathrm{CI})$ & $\mathrm{RC}^{1}\left(95 \% \mathrm{CI}^{2}\right)$ & $p$-Value & ICC $^{3}(95 \%$ IC) \\
\hline \multicolumn{7}{|c|}{ All-cause mortality } \\
\hline Agriculture ${ }^{4}$ & $-0.01(-0.04$ to 0.43$)$ & 0.726 & $0.24(0.01 \text { to } 0.92)^{5}$ & $-0.04(-0.27$ to 0.20$)$ & 0.761 & $0.25(0.00-0.91)$ \\
\hline Vegetables ${ }^{4}$ & $-0.19(-0.31$ to -0.07$)$ & 0.003 & $\mathrm{NC}^{6}$ & $-1.76(-2.88$ to -0.63$)$ & 0.002 & $\mathrm{NC}^{6}$ \\
\hline Artichokes 4 & $-0.42(-0.62$ to -0.11$)$ & 0.003 & $\mathrm{NC}^{6}$ & $-3.92(-6.41$ to -1.42$)$ & 0.002 & $\mathrm{NC}^{6}$ \\
\hline Citrus $^{4}$ & $0.03(-0.01$ to 0.07$)$ & 0.196 & $0.16(0.00 \text { to } 0.97)^{5}$ & $0.25(-0.11$ to 0.61$)$ & 0.178 & 0.15 (0.00 to 0.97$)$ \\
\hline \multicolumn{7}{|c|}{ Cardiovascular disease (CVD) mortality } \\
\hline Agriculture ${ }^{4}$ & $-0.02(-0.05$ to 0.01$)$ & 0.169 & $0.23(0.01$ to 0.92$)$ & $-0.05(-0.17$ to 0.06$)$ & 0.376 & $\mathrm{NC}^{6}$ \\
\hline Vegetables $^{4}$ & $-0.20(-0.36$ to -0.03$)$ & 0.017 & $0.07(0.00$ to 0.99$)$ & $-0.58(-1.33$ to 0.16$)$ & 0.126 & $\mathrm{NC}^{6}$ \\
\hline Artichokes ${ }^{4}$ & $-0.42(-0.79$ to -0.04$)$ & 0.028 & $0.10(0.00$ to 0.99$)$ & $-1.20(-2.88$ to 0.48$)$ & 0.161 & $\mathrm{NC}^{6}$ \\
\hline Citrus $^{4}$ & $0.02(-0.01$ to 0.06$)$ & 0.137 & 0.88 (0.50 to 0.98$)$ & $-0.02(-0.22$ to 0.18$)$ & 0.862 & $\mathrm{NC}^{6}$ \\
\hline \multicolumn{7}{|c|}{ Cerebrovascular disease (CED) mortality } \\
\hline Agriculture ${ }^{4}$ & $-0.05(-0.14$ to 0.04$)$ & 0.309 & $0.82(0.54$ to 0.96$)$ & $-0.04(-0.14$ to 0.05$)$ & 0.372 & $0.62(0.21$ to 0.90$)$ \\
\hline Vegetables ${ }^{4}$ & $-0.68(-1.16$ to -0.19$)$ & 0.006 & $0.72(0.33$ to 0.93$)$ & $-0.71(-1.18$ to -0.24$)$ & 0.003 & 0.39 (0.05 to 0.88$)$ \\
\hline Artichokes 4 & $-1.47(-2.57$ to -0.36$)$ & 0.000 & $0.73(0.35$ to 0.93$)$ & $-1.54(-2.16$ to -0.47$)$ & 0.005 & 0.41 (0.06 to 0.88$)$ \\
\hline Citrus $^{4}$ & $0.04(-0.13$ to 0.21$)$ & 0.623 & $0.84(0.54 \text { to } 0.96)^{5}$ & $0.05(-0.12$ to 0.22$)$ & 0.544 & $0.64(0.23$ to 0.99$)$ \\
\hline \multicolumn{7}{|c|}{ Ischaemic heart disease (IHD) mortality } \\
\hline Agriculture $^{4}$ & $0.01(-0.05$ to 0.07$)$ & 0.771 & $\mathrm{NC}^{6}$ & $0.01(-0.02$ to 0.03$)$ & 0.651 & 0.19 (0.0 to 0.95$)$ \\
\hline Vegetables $^{4}$ & $-0.36(-0.76$ to 0.03$)$ & 0.067 & $\mathrm{NC}^{6}$ & $-0.21(-0.31$ to -0.12$)$ & 0.000 & $\mathrm{NC}^{6}$ \\
\hline Artichokes 4 & $-0.78(-1.65$ to 0.10$)$ & 0.083 & $\mathrm{NC}^{6}$ & $-0.46(-0.68$ to -0.25$)$ & 0.000 & $\mathrm{NC}^{6}$ \\
\hline Citrus $^{4}$ & $0.30(-0.07$ to 0.14$)$ & 0.548 & $\mathrm{NC}^{6}$ & $0.03(-0.01$ to 0.06$)$ & 0.104 & $0.06(0.00$ to 0.99$)$ \\
\hline \multicolumn{7}{|c|}{ Cerebrovascular disease (CED) and ischaemic heart disease (IHD) mortality } \\
\hline Agriculture $^{4}$ & $-0.02(-0.10$ to 0.05$)$ & 0.509 & $0.80(0.47 \text { to } 0.95)^{5}$ & $-0.04(0.15$ to 0.08$)$ & 0.528 & $0.80(0.45 \text { to } 0.95)^{5}$ \\
\hline Vegetables ${ }^{4}$ & $-0.57(-0.89$ to -0.26$)$ & 0.000 & $0.59(0.18$ to 0.90$)$ & $-0.92(-1.41$ to -0.42$)$ & 0.000 & $0.56(0.16$ to 0.90$)$ \\
\hline Artichokes 4 & $-1.24(-1.97$ to -0.52$)$ & 0.001 & $0.61(0.20$ to 0.91$)$ & $-2.00(-3.14$ to -0.86$)$ & 0.001 & $0.58(0.17$ to 0.90$)$ \\
\hline Citrus ${ }^{4}$ & $0.05(-0.07$ to 0.17$)$ & 0.434 & $0.80(0.47 \text { to } 0.95)^{5}$ & $0.08(-0.12$ to 0.28$)$ & 0.421 & $0.79(0.44 \text { to } 0.95)^{5}$ \\
\hline
\end{tabular}

${ }^{1} \mathrm{RC}=$ Regression coefficient ${ }^{2} \mathrm{CI}=$ confidence interval. ${ }^{3} \mathrm{ICC}=$ interclass correlation ${ }^{4}$ Hectare production per 1000 inhabitants. ${ }^{5}$ Likelihood ratio test $($ LRT $)$ value $>0.05{ }^{6}$. NC $=$ Not computable. 


\section{Discussion}

Our results support that the production of vegetables and artichokes may be protective for CED mortality and, to a lesser extent, for CVD mortality. A non-significant effect was observed in IHD mortality. All-cause mortality was inversely associated with the production of vegetables and artichokes, but with a low ICC. By contrast, CVD, CED and IHD mortalities were not associated with agricultural and citrus production, suggesting some specificity for the estimated protective effects of vegetables and artichokes.

In the sensitivity analyses of the AMRs, we obtained results similar to the SMRs in respect to CED and all-cause mortalities, but the CVD mortality association with vegetable and artichoke production was not significant. The autocorrelation did not indicate a general spatial dependence and other municipality-related factors could have played a role. Our findings support that SMRs and AMRs may be adequate for spatial analysis of CED mortality.

CVD is related to many risks and protecting factors, including socio-economic and personal factors, such as lifestyle, social class, diet, stress, air pollution, health, genetic conditions, and health care systems [31-36]. In our study, Borriana presented high all-cause, CVD, and CED mortalities; this situation may be related with the elevated prevalence of type 2 diabetes mellitus and obesity reported there in a 2006 publication [37]. All-cause, CVD, and CED mortalities have been associated with blue water and green space [38,39]. In addition, water hardness and CVD mortality's relationship has been studied for a long time but controversy remains [40,41]. The hardness of drinking water (calcium and magnesium concentrations) was associated with CED and IHD mortalities in a study of CVD at a municipal level in the CV [9]; when the level of magnesium was controlled in the models, the SMRs of CED mortality increased, which suggested a protecting effect apart from other unknown factors. Interestingly, psychosocial stress has been shown as a more predominant risk factor in IHD mortality than in CED. We hypothesize that vegetable and artichoke consumption may be less protective for psychosocial stress than for CED mortality, therefore, this could explain the non-significant effect observed on IHD mortality [42].

Regarding the effects of pesticides and fertilizers on CVD mortality [43], the ecological (organic) agriculture was small in the Castellón province during the 1991-2011 period; the median of hectares with ecological agriculture of irrigated cultivation of vegetables was 18.33 , and this number represented $1.1 \%$ of the median of 1740 hectares of irrigated cultivation of vegetables in the eight municipalities during the same period [44,45].

In our DAG approach, we did not consider factors that were not related to agricultural production. However, in our multilevel models, we studied other factors, considering their relation to CED mortality and vegetable and artichoke production, such as unemployment, particulate matter (PM10) and nitrogen dioxide (NO2) levels, coastal proximity, and drinking water hardness. In all models, direction and significance were maintained for these factors. Water hardness, air pollution indicators (PM10 and NO2), and unemployment produced a decline in the protecting effects of the production of artichokes and vegetables. Water hardness and coastal proximity had fewer effects on the estimates. Overall, these results suggest that vegetable and artichoke production are protective factors with independence of some known factors of CVD mortality.

In ecological studies, CVD mortality (CED, IHD, and hypertensive disease) has been associated with social inequalities and low socio-economic levels [46,47], and low mortality has been observed in rural non-metropolitan counties with agricultural production in the United States [48]. Changes in agricultural production, food processing, and diet in European Mediterranean countries have been related to an increase in CVD incidence [49]. In our study, all-cause, CVD, and CED mortalities were lower with the presence of vegetable and artichoke production, but we found no changes in mortality related to agricultural or citrus production. The largest decline in CVD and CED mortalities associated with artichokes and vegetables production was found in Benicarló. Lower IHD mortality has been associated with fruit and vegetable consumption [50], but not in our study and others [51]. The eight municipalities in our study had differences in agricultural production which may explain 
CVD mortality variations. In general, a diet with vegetables and fruits is associated with lower all-cause, CVD, and CED mortalities [52-55]. Apart from artichokes, vegetable cultivation included salads, cauliflowers, cabbages, tomatoes, and onions. Specifically, the consumption of vegetables, including that of cruciferous vegetables (i.e., cauliflowers and cabbages, among others), has been associated with a decline of all-cause, CVD, and CED mortalities. Physiologically, protective effects associated with vegetables include anti-oxidant and anti-inflammatory actions, inhibition of platelet aggregation, lowering of blood pressure, and glucose and lipid metabolism regulation $[18,56,57]$.

Artichokes have several healthy properties including antioxidant activity, lipid and cholesterol reduction, and a decrease in postprandial glycemic and insulin response [58-60]. Components of artichokes which have an effect are caffeic acid derivatives, flavonoids, such as luteolin, cynaroside, scolymoside, and cynarotrioside and sesquiterpenic lactones; artichokes decrease production of cholesterol and endogenous triglycerides and increase their excretion by bile production [21,61,62]. In several clinical trials, reductions in cholesterol levels were found but more studies are needed [63-66]. In addition, improved hypertension, body mass index, cardio-metabolic parameters, and hepato-protective effects have been observed [67-69]. Artichoke extract may be relevant as a therapeutic factor for atherosclerosis due to it lowering the rates of low-density-lipoprotein cholesterol and by its antioxidant, anti-inflammatory, and nitric oxide regulation effects [70-75].

We hypothesized that the production of vegetables and artichokes may be a proxy of their consumption in our ecological approach. Considering the high production of vegetables and artichokes in Benicarló, it is plausible that vegetable and artichoke consumption may be more elevated than in the other municipalities due to higher accessibility, lower price, different diet habits related with own vegetable production, and the elevated proportion of people with agricultural occupations. More than 200 farmers of Benicarló, Vinaròs, and neighboring towns work in the cultivation of artichokes. In addition, since 1998, the artichoke of Benicarló is an appellation of origin, and since 2003, it holds a Denomination of Protected Origin of the European Commission. A week of artichoke consumption has been celebrated each year since 1993 where artichoke culinary recipes are presented in many restaurants of Benicarló as a part of a multitudinous set of events with artichokes as the protagonist [76,77]. On the other hand, agricultural lands are well distributed with small exploitations, which have a mean of 5.47 hectares per owner in the CV with a Gini index of 0.45 [78]. In the eight municipalities, the median of farm surface per owner was 3.70 hectares (rank 2.06 Castelló de la Plana, 9.97 Benicarló). The health effects of gardening have been indicated and Benicarló has a high agricultural occupation percentage [79].

The study limitations include its ecological design with aggregate data susceptible to ecological fallacy. In addition, other potential confounders related with CVD mortality, such as existing co-morbidities and family history of CVD of this population, were not studied, which we could consider another limitation of our study. However, we obtained similar results with the AMR sensitivity analysis. We assumed that the production of vegetables and artichokes was a proxy of their consumption but studies to verify this point are necessary. Our retrospective approach could increase potential bias; there were few socio-economic data at a municipal level; some residual confounding could affect our estimates, some differences among municipalities may persist, genetic predisposition to CVD of the population [80] was not studied, and finally, we cannot discard the impact of unmeasured or unknown factors.

A strength of the study is that CVD was estimated by SMRs and AMRs in a substantial twenty-year period; the study encompassed relatively small areas with similar climates and small socio-economic differences, and we used multilevel models to adjust for variables considered to be potential confounders and other unknown municipality related effects.

Our new research proposal includes a cross-sectional survey of a representative sample in each municipality to obtain a background of CVD risk factors and co-morbidities, jointly with food consumption, diet, habits, and demographic characteristics as a first step. The survey's results could support the relationship between the consumption of vegetables and artichokes and CVD and CED 
mortalities, and it could facilitate the rationale for accurate preventive strategies. As a second step, we recommend a properly powered cohort approach with sufficient follow-up on a population-based study of the first step.

\section{Conclusions}

Our study suggests that the production of vegetables and artichokes may be a protective factor of CED and CVD mortality. Our recommendation is to continue this research using a cohort approach in the eight municipalities.

Author Contributions: Conceptualization, A.A.-P., J.B.-B., M.R.P.-S., M.A.R.-G.; Methodology, J.P.-B., J.B.-B., F.G.-G.; validation, J.P.-B., M.A.R.-G.; Formal analysis, A.A.-P., M.R.P.-S., J.P.-B.; Writing-Original draft preparation, A.A.-P., J.P.-B., M.A.R.-G.; Writing-Review and editing, A.A.-P., J.P.-B., J.B.-B., F.G.-G., M.R.P.-S.; supervision, J.P.-B., M.A.R.-G., F.G.-G. All authors have read and agreed to the published version of the manuscript.

Funding: This research received no external funding.

Acknowledgments: We thank Claudia Arnedo-Pac, José Antonio Valer-Ratera, Lourdes Safont-Adsuara, Ana Vizcaino-Batllés, Noemi Messeguer-Ferrer N, and Juan Carlos Gascó-Laborda for their help during the preparation of this study.

Conflicts of Interest: The authors declare no conflict of interest.

\section{References}

1. Harper, S.; Lynch, J.; Smith, G.D. Social determinants and the decline of cardiovascular diseases: Understanding the links. Annu. Rev. Public Health 2011, 32, 39-69. [CrossRef] [PubMed]

2. Ezzati, M.; Obermeyer, Z.; Tzoulaki, I.; Mayosi, B.M.; Elliott, P.; Leon, D.A. Contributions of risk factors and medical care to cardiovascular mortality trends. Nat. Rev. Cardiol. 2015, 12, 508-530. [CrossRef] [PubMed]

3. Kim, K.; Hyeon, J.; Lee, S.A.; Kwon, S.O.; Lee, H.; Keum, N.; Lee, J.K.; Park, S.M. Role of total, red, processed, and white meat consumption in stroke incidence and mortality: A systematic review and meta-analysis of prospective cohort studies. J. Am. Heart Assoc. 2017, 6, e005983. [CrossRef] [PubMed]

4. Meier, T.; Gräfe, K.; Senn, F.; Sur, P.; Stangl, G.I.; Dawczynski, C.; März, W.; Kleber, M.E.; Lorkowski, S. Cardiovascular mortality attributable to dietary risk factors in 51 countries in the WHO European Region from 1990 to 2016: A systematic analysis of the Global Burden of Disease Study. Eur. J. Epidemiol. 2019, 34, 37-55. [CrossRef]

5. Grau, M.; Elosua, R.; Cabrera de León, A.; Guembe, M.J.; Baena-Díez, J.M.; Vega Alonso, T.; Javier Félix, F.; Zorrilla, B.; Rigo, F.; Lapetra, J.; et al. Factores de riesgo cardiovascular en España en la primera década del siglo xxi: Análisis agrupado con datos individuales de 11 estudios de base poblacional, estudio DARIOS. Rev. Esp. Cardiol. 2011, 64, 295-304. [CrossRef]

6. Roth, G.A.; Dwyer-Lindgren, L.; Bertozzi-Villa, A.; Stubbs, R.W.; Morozoff, C.; Naghavi, M.; Mokdad, A.H.; Murray, C.J.L. Trends and patterns of geographic variation in cardiovascular mortality among US counties, 1980-2014. JAMA 2017, 317, 1976-1992. [CrossRef]

7. Mena, C.; Sepúlveda, C.; Fuentes, E.; Ormazábal, Y.; Palomo, I. Spatial analysis for the epidemiological study of cardiovascular diseases: A systematic literature search. Geospat. Health 2018, 13, 587. [CrossRef]

8. Rajabi, M.; Mansourian, A.; Pilesjö, P.; Åström, D.O.; Cederin, K.; Sundquist, K. Exploring spatial patterns of cardiovascular disease in Sweden between 2000 and 2010. Scand. J. Public Health 2018, 46, 647-658. [CrossRef]

9. Ferrandiz, J.; Abellan, J.J; Gomez-Rubio, V.; Lopez-Quilez, A.; Sanmartin, P.; Abellan, C.; Martinez-Beneito, M.A.; Melchor, I.; Vanaclocha, H.; Zurriaga, O.; et al. Spatial analysis of the relationship between mortality from cardiovascular and cerebrovascular disease and drinking water hardness. Environ. Health Perspect. 2004, 112, 1037-1044. [CrossRef]

10. Maheswaran, R.; Haining, R.P.; Brindley, P.; Law, J.; Pearson, T.; Fryers, P.R.; Wise, S.; Campbell, M.J. Outdoor air pollution and stroke in Sheffield, United Kingdom: A small-area level geographical study. Stroke 2005, 36, 239-243. [CrossRef]

11. Gómez-Barroso, D.; Prieto-Flores, M.E.; Mellado San Gabino, A.; Moreno Jiménez, A. Análisis espacial de la mortalidad por enfermedades cardiovasculares en la ciudad de Madrid, España. Rev. Esp. Salud Publica 2015, 89, 27-37. [CrossRef] [PubMed] 
12. Wróblewska, W. Territorial variation in mortality from causes amenable to medical care in Poland. Ann. Agric. Environ. Med. 2017, 24, 489-495. [CrossRef] [PubMed]

13. AGEPI: Analisis Geográfico Epidemiológico. Programa de Mortalidad de la Comunidad Valenciana. Valencia Conselleria de Sanitat 2005. Available online: http://www.agepi.es (accessed on 11 July 2017).

14. Lopez-Quilez, A.; Verdejo, F.; Zurriaga, O.; Botella, P.; Vanaclocha, H.; Martinez-Beneito, M.A.; Amador, A. AGEPI (Analisis Geografico Epidemiologico): Una herramienta para cartografia de enfermedades. Logroño: XXIV Reunión de la Sociedad Española de Epidemiología 2006. Gac. Sanit. 2006, 20, 78.

15. Martinez-Beneito, M.A.; Lopez-Quiles, A.; Amador-Iscla, A.; Melchor-Alos, I.; Botella-Rocamora, P.; Abellan-Andres, C.; Abellan-Andres, J.J.; Verdejo-Mañez, F.; Zurriaga-Lloréns, O.; Vanaclocha-Lina, H.; et al. Altas de mortalidad de la Comunidad Valenciana. 1991-2000. Valencia Generaliata Valenciana. Coselleria de Sanitat. 2005. Available online: http://san.gva.es/publicaciones/documentos/V.5093-2005.pdf (accessed on 8 September 2020).

16. Corpas-Burgos, F.; Vergara-Hernandez, Botella-Rocamora, P.; Perez-Panades, J.; Perpiñan-Faubel, H.; Martinez-Beneito, M.A. Atlas nacional de mortalidad de España (ANDEES). FISABIO-Generalidad Valenciana 2020. Available online: http://fisabio.san.gva.es/desigualdades-en-salud. (accessed on 8 September 2020).

17. Aune, D.; Giovannucci, E.; Boffetta, P.; Fadnes, L.T.; Keum, N.; Norat, T.; Greenwood, D.C.; Riboli, E.; Vatten, L.J.; Tonstad, S. Fruit and vegetable intake and the risk of cardiovascular disease, total cancer and all-cause mortality-a systematic review and dose-response meta-analysis of prospective studies. Int. J. Epidemiol. 2017, 46, 1029-1056. [CrossRef] [PubMed]

18. Conrad, Z.; Thomson, J.; Jahns, L. Prospective analysis of vegetable amount and variety on the risk of all-cause and cause-specific mortality among US adults, 1999-2011. Nutrients 2018, 10, 1377. [CrossRef]

19. Tang, G.Y.; Meng, X.; Li, Y.; Zhao, C.N.; Liu, Q.; Li, H.B. Effects of vegetables on cardiovascular diseases and related mechanisms. Nutrients 2017, 9, 857. [CrossRef]

20. Pandino, G.; Lombardo, S.; Mauromicale, G. Mineral profile in globe artichoke as affected by genotype, head part and environment. J. Sci. Food Agric. 2011, 91, 302-308. [CrossRef]

21. Rondanelli, M.; Giacosa, A.; Morazzoni, P.; Guido, D.; Grassi, M.; Morandi, G.; Bologna, C.; Riva, A.; Allegrini, P.; Perna, S. MediterrAsian diet products that could raise HDL-cholesterol: A systematic review. Biomed. Res. Int. 2016, 2016, 2025687. [CrossRef]

22. Ministerio de Sanidad, Consumo y Bienestar Social. Madrid 2008. Available online: https://www.mscbs.gob. es/estadEstudios/estadisticas/estadisticas/estMinisterio/SIAP/Estadisticas.htm/ (accessed on 20 August 2020).

23. World Health Organization. The International Classification of Diseases (ICD) 9th and 10th Edition; World Health Organization: Geneva, Switzerland, 2010.

24. Argos. Banco de Datos Municipales. Valencia: Generalitat Valenciana. Available online: www.argos.gva.es (accessed on 22 January 2020).

25. Generalitat Valenciana: Portal Estadístico. Banco de Datos de Series. Municipios y Comarcas. Banco de Datos Territorial. Available online: http://www.pegv.gva.es/es/bdt (accessed on 21 January 2020).

26. Instituto Nacional de Estadística. Censos de Población y Viviendas 2001-2011. Madrid: Instituto Nacional de Estadistica. Available online: www.ine.es (accessed on 8 January 2020).

27. Clayton, D.; Kaldor, J. Empirical Bayes estimates of age-standarized relative risks for use in disease mapping. Biometrics 1987, 43, 671-681. [CrossRef]

28. Mollié, A. Bayesian mapping of Hodgkin's disease in France. In Spacial Epidemiology: Methods and Applications; Elliot, P., Wakefield, J., Best, N., Briggs, D., Eds.; Oxford University Press: New York, NY, USA, 2001; pp. 267-285.

29. Textor, J.; Van der Zander, B.; Gilthorpe, M.K.; Liskiewicz, M.; Ellison, G.T.H. Robust causal inference using directed acyclic graphs: The R package 'dagitty'. Int. J. Epidemiol. 2016, 45, 1887-1894. [CrossRef]

30. Moran, P.A.P. The interpretation of statistical maps. J. R. Stat. Soc. Ser. B 1948, 10, 243-251. [CrossRef]

31. Francula-Zaninovic, S.; Nola, I.A. Management of measurable variable cardiovascular disease' risk factors. Curr. Cardiol. Rev. 2018, 14, 153-163. [CrossRef]

32. Orozco-Beltran, D.; Gil-Guillen, V.F.; Redon, J.; Martin-Moreno, J.M.; Pallares-Carratala, V.; Navarro-Perez, J.; Valls-Roca, F.; Sanchis-Domenech, C.; Fernandez-Gimenez, A.; Perez-Navarro, A.; et al. Lipid profile, cardiovascular disease and mortality in a Mediterranean high-risk population: The ESCARVAL-RISK study. PLoS ONE 2017, 12, e0186196. [CrossRef] [PubMed] 
33. Appelman, Y.; Van Rijn, B.B.; Ten Haaf, M.E.; Boersma, E.; Peters, S.A. Sex differences in cardiovascular risk factors and disease prevention. Atherosclerosis 2015, 241, 211-218. [CrossRef]

34. Fiordelisi, A.; Piscitelli, P.; Trimarco, B.; Coscioni, E.; Iaccarino, G.; Sorriento, D. The mechanisms of air pollution and particulate matter in cardiovascular diseases. Heart Fail. Rev. 2017, 22, 337-347. [CrossRef] [PubMed]

35. Rajagopalan, S.; Al-Kindi, S.G.; Brook, R.D. Air pollution and cardiovascular disease: JACC State-of-the-Art Review. J. Am. Coll. Cardiol. 2018, 72, 2054-2070. [CrossRef]

36. Martínez-García, M.; Salinas-Ortega, M.; Estrada-Arriaga, I.; Hernández-Lemus, E.; García-Herrera, R.; Vallejo, M. A systematic approach to analyze the social determinants of cardiovascular disease. PLoS ONE 2018, 13, e0190960. [CrossRef]

37. Pallares-Carratala, V.; Piñón-Selles, F.; Diago-Torrent, J.L.; en nombre de los investigadores del estudio Burriana. Diabetes mellitus y otros factores de riesgo cardiovascular mayores en una población del Mediterraneo español. Estudio Burriana. Endocrinol. Nutr. 2006, 53, 158-167. [CrossRef]

38. Crouse, D.L.; Balram, A.; Hystad, P.; Pinault, L.; Van den Bosch, M.; Chen, H.; Rainham, D.; Thomson, E.M.; Close, C.H.; Van Donkelaar, A.; et al. Associations between living near water and risk of mortality among urban Canadians. Environ. Health Perspect. 2018, 126, 077008. [CrossRef]

39. Nieuwenhuijsen, M.J.; Gascon, M.; Martinez, D.; Ponjoan, A.; Blanch, J.; Garcia-Gil, M.D.M.; Ramos, R.; Foraster, M.; Mueller, N.; Espinosa, A.; et al. Air pollution, noise, blue space, and green space and premature mortality in Barcelona: A mega cohort. Int. J. Environ. Res. Public Health 2018, 15, 2405. [CrossRef]

40. Leurs, L.J.; Schouten, L.J.; Mons, M.N.; Goldbohm, R.A.; Van den Brandt, P.A. Relationship between tap water hardness, magnesium, and calcium concentration and mortality due to ischemic heart disease or stroke in The Netherlands. Environ. Health Perspect. 2010, 118, 414-420. [CrossRef] [PubMed]

41. Sengupta, P. Potential health impacts of hard water. Int. J. Prev. Med. 2013, 4, 866-875.

42. Fioranelli, M.; Bottaccioli, A.G.; Bottaccioli, F.; Bianchi, M.; Rovesti, M.; Roccia, M.G. Stress and inflammation in coronary artery disease: A review psychoneuroendocrineimmunology-based. Front. Immunol. 2018, 9 , 2031. [CrossRef]

43. Sekhotha, M.M.; Monyeki, K.D.; Sibuyi, M.E. Exposure to agrochemicals and cardiovascular disease: A review. Int. J. Environ. Res. Public Health 2016, 13, 229. [CrossRef]

44. Comité d'Agricultura Ecológica de la Comunitat Valenciana. Estadisticas. Hectareas de Producción. Available online: https://www.caecv.com/ (accessed on 21 August 2020).

45. Portal Estadístico de la Generalitat Valenciana. Superficies de Cultivo de Hortalizas de Regadío Por Municipio 2002-2011. Available online: http://www.pegv.gva.es/es/bdt (accessed on 21 August 2020).

46. Cardona, D.; Cerezo Mdel, P.; Parra, H.; Quintero, L.; Muñoz, L.; Cifuentes, O.L.; Vélez, S.C. Desigualdades en la mortalidad por enfermedades cardiovasculares en los municipios del Eje Cafetero, 2009-2011. Biomedica 2015, 35, 379-394. [CrossRef] [PubMed]

47. Karp, D.N.; Wolff, C.S.; Wiebe, D.J.; Branas, C.C.; Carr, B.G.; Mullen, M.T. Reassessing the stroke belt: Using small area spatial statistics to identify clusters of high stroke mortality in the United States. Stroke 2016, 47, 1939-1942. [CrossRef] [PubMed]

48. Hendryx, M.; Fedorko, E.; Halverson, J. Pollution sources and mortality rates across rural-urban areas in the United States. J. Rural Health 2010, 26, 383-391. [CrossRef]

49. Ghebremeskel, K.; Crawford, M.A. Nutrition and health in relation to food production and processing. Nutr. Health 1994, 9, 237-253. [CrossRef]

50. Bhupathiraju, S.N.; Wedick, N.M.; Pan, A.; Manson, J.E.; Rexrode, K.M.; Willett, W.C.; Rimm, E.B.; Hu, F.B. Quantity and variety in fruit and vegetable intake and risk of coronary heart disease. Am. J. Clin. Nutr. 2013, 98, 1514-1523. [CrossRef]

51. Besson, H.; Paccaud, F.; Marques-Vidal, P. Ecologic correlations of selected food groups with disease incidence and mortality in Switzerland. J. Epidemiol. 2013, 23, 466-473. [CrossRef]

52. Atkins, J.L.; Whincup, P.H.; Morris, R.W.; Lennon, L.T.; Papacosta, O.; Wannamethee, S.G. Dietary patterns and the risk of CVD and all-cause mortality in older British men. Br. J. Nutr 2016, 116, 1246-1255. [CrossRef] [PubMed]

53. Price, H.C.; Nicholls, A. Primary prevention of CVD: Diet. BMJ Clin. Evid. 2014, 2014, 0219. [PubMed] 
54. Misirli, G.; Benetou, V.; Lagiou, P.; Bamia, C.; Trichopoulos, D.; Trichopoulou, A. Relation of the traditional Mediterranean diet to cerebrovascular disease in a Mediterranean population. Am. J. Epidemiol. 2012, 176, 1185-1192. [CrossRef] [PubMed]

55. Gillman, M.W.; Cupples, L.A.; Gagnon, D.; Posner, B.M.; Ellison, R.C.; Castelli, W.P.; Wolf, P.A. Protective effect of fruits and vegetables on development of stroke in men. JAMA 1995, 273, 1113-1117. [CrossRef] [PubMed]

56. Mori, N.; Shimazu, T.; Charvat, H.; Mutoh, M.; Sawada, N.; Iwasaki, M.; Yamaji, T.; Inoue, M.; Goto, A.; Takachi, R.; et al. Cruciferous vegetable intake and mortality in middle-aged adults: A prospective cohort study. Clin. Nutr. 2019, 38, 631-643. [CrossRef]

57. Miller, V.; Mente, A.; Dehghan, M.; Rangarajan, S.; Zhang, X.; Swaminathan, S.; Dagenais, G.; Gupta, R.; Mohan, V.; Lear, S.; et al. Fruit, vegetable, and legume intake, and cardiovascular disease and deaths in 18 countries (PURE): A prospective cohort study. Lancet 2017, 390, 2037-2049. [CrossRef]

58. Banach, M.; Patti, A.M.; Giglio, R.V.; Cicero, A.F.G.; Atanasov, A.G.; Bajraktari, G.; Bruckert, E.; Descamps, O.; Djuric, D.M.; Ezhov, M.; et al. The role of nutraceuticals in statin intolerant patients. J. Am. Coll Cardiol. 2018, 72, 96-118. [CrossRef]

59. Ben Salem, M.; Affes, H.; Ksouda, K.; Dhouibi, R.; Sahnoun, Z.; Hammami, S.; Zeghal, K.M. Pharmacological studies of artichoke leaf extract and their health benefits. Plant. Foods Hum. Nutr. 2015, 70, 441-453. [CrossRef]

60. Ben Salem, M.; Affes, H.; Dhouibi, R.; Charfi, S.; Turki, M.; Hammami, S.; Ayedi, F.; Sahnoun, Z.; Zeghal, K.M.; Ksouda, K. Effect of artichoke (Cynara scolymus) on cardiac markers, lipid profile and antioxidants levels in tissue of HFD-induced obesity. Arch. Physiol. Biochem. 2019, 1-7. [CrossRef]

61. Rondanelli, M.; Monteferrario, F.; Perna, S.; Faliva, M.A.; Opizzi, A. Health-promoting properties of artichoke in preventing cardiovascular disease by its lipidic and glycemic-reducing action. Monaldi Arch. Chest Dis. 2013, 80, 17-26. [CrossRef]

62. Cicero, A.F.G.; Fogacci, F.; Bove, M.; Giovannini, M.; Veronesi, M.; Borghi, C. Short-Term effects of dry extracts of artichokeand berberis in hypercholesterolemic patients without cardiovascular disease. Am. J. Cardiol. 2019, 123, 588-591. [CrossRef]

63. Pittler, M.H.; Thompson, C.O.; Ernst, E. Artichoke leaf extract for treating hypercholesterolaemia. Cochrane Database Syst. Rev. 2002, 3, CD003335.

64. Wider, B.; Pittler, M.H.; Thompson-Coon, J.; Ernst, E. Artichoke leaf extract for treating hypercholesterolaemia. Cochrane Database Syst. Rev. 2009, 4, CD003335.

65. Wider, B.; Pittler, M.H.; Thompson-Coon, J.; Ernst, E. Artichoke leaf extract for treating hypercholesterolaemia. Cochrane Database Syst. Rev. 2013, 3, CD003335.

66. Santos, H.O.; Bueno, A.A.; Mota, J.F. The effect of artichoke on lipid profile: A review of possible mechanisms of action. Pharmacol. Res. 2018, 137, 170-178. [CrossRef]

67. Roghani-Dehkordi, F.; Kamkhah, A.F. Artichoke leaf juice contains antihypertensive effect in patients with mild hypertension. J. Diet. Suppl. 2009, 6, 328-341. [CrossRef]

68. Khan, M.Y.; Kumar, V. Mechanism \& inhibition kinetics of bioassay-guided fractions of Indian medicinal plants and foods as ACE inhibitors. J. Tradit. Complement Med. 2018, 9, 73-84.

69. Ardalani, H.; Jandaghi, P.; Meraji, A.; Hassanpour Moghadam, M. The Effect of Cynara scolymus on blood pressure and BMI in hypertensive patients: A randomized, double-blind, placebo-controlled, clinical trial. Complement Med. Res. 2019, 27, 40-46. [CrossRef]

70. Castellino, G.; Nikolic, D.; Magán-Fernández, A.; Malfa, G.A.; Chianetta, R.; Patti, A.M.; Amato, A.; Montalto, G.; Toth, P.P.; Banach, M.; et al. Altilix@supplement containing chlorogenic acid and luteolin improved hepatic and cardiometabolic parameters in subjects with metabolic syndrome: A 6 month randomized, double-blind, placebo-controlled study. Nutrients 2019, 25, 2580. [CrossRef]

71. Bjørklund, G.; Dadar, M.; Martins, N.; Chirumbolo, S.; Goh, B.H.; Smetanina, K.; Lysiuk, R. Brief challenges on medicinal plants: An eye-opening look at ageing-related disorders. Basic. Clin. Pharmacol. Toxicol. 2018, 122, 539-558. [CrossRef]

72. D'Antuono, I.; Carola, A.; Sena, L.M.; Linsalata, V.; Cardinali, A.; Logrieco, A.F.; Colucci, M.G.; Apone, F. Artichoke polyphenols produce skin anti-Age effects by improving endothelial cell integrity and functionality. Molecules 2018, 23, 2729. [CrossRef] [PubMed] 
73. Sahebkar, A.; Pirro, M.; Banach, M.; Mikhailidis, D.P.; Atkin, S.L.; Cicero, A.F.G. Lipid-lowering activity of artichoke extracts: A systematic review and meta-analysis. Crit. Rev. Food Sci. Nutr. 2018, 58, 2549-2556. [CrossRef] [PubMed]

74. Waltenberger, B.; Mocan, A.; Šmejkal, K.; Heiss, E.H.; Atanasov, A.G. Natural products to counteract the epidemic of cardiovascular and metabolic disorders. Version 2. Molecules 2016, 21, 807. [CrossRef] [PubMed]

75. Xia, N.; Pautz, A.; Wollscheid, U.; Reifenberg, G.; Förstermann, U.; Li, H. Artichoke, cynarin and cyanidin downregulate the expression of inducible nitric oxide synthase in human coronary smooth muscle cells. Molecules 2014, 19, 3654-3668. [CrossRef]

76. Ayuntamiento de Benicarló. La Carxofa de Benicarlò. Available online: https://www.ajuntamentdebenicarlo. org/car/pcar-carxofa.php?g_idioma=v (accessed on 20 August 2020).

77. Maura, J. Coordinador. In Els Millors Pinxos i Tapes de la Carxofa de Benicarló; Onada Editions: Benicarló, Spain, 2015.

78. Soler, C.; Fernandez, F. Estructura de la Propiedad de Tierras en España; Fundación Mundubat Revista Soberania Alimentaria Biodiversidad Culturas: Bilbao, Spain, 2015.

79. Thompson, R. Gardening for health: A regular dose of gardening. Clin. Med. 2018, 18, 201-205. [CrossRef] [PubMed]

80. Kathiresan, S.; Srivastava, D. Genetics of human cardiovascular disease. Cell 2012, 148, 1242-1257. [CrossRef]

(C) 2020 by the authors. Licensee MDPI, Basel, Switzerland. This article is an open access article distributed under the terms and conditions of the Creative Commons Attribution (CC BY) license (http://creativecommons.org/licenses/by/4.0/). 